\title{
Insulin and Hypothalamo-Pituitary Adrenal System
}

\author{
By
}

\author{
Yoshihiko HAYASHI \\ From the First Department of Internal Medicine, University School of Medicine, \\ Nagoya University. (Director: Prof. S. Hibino)
}

\begin{abstract}
Insulin given exogeneously changes the hormone balance in which hypothalamo pituitary adrenal system plays an impertant role and these changes are reflected in the fluctuations of the several components of body fluids. As, among these, the pattern of ciaculating eosinophil leucocytes count considerably relates with function of hypothalamo-pituitary adrenal system, I attempted a test method for this system, using eosinophil count as an indicator after subcutaneous injection of insulin 0.15 unit per Kg. Body weight in fasting state, and investigated the responses in various neuro-endocrine disorders.
\end{abstract}

In healthy controls, 50 per cent decrease of eosinophils occurred 4 hours after injection of insulin.

By the prevention of hypoglycemia with glucose administration, eosinopenia was not induced in healthy controls. Adrenolytic agent and hypnotica (Isomital) change the pattern of eosinopenia. Therefore, the response is primarily conditioned by the hypoglycemia and is related with neural factors.

Abnormal responses of eosinophils were found in all cases of adrenocortical insufficiency. This finding suggests that the insulin eosinopenia occurrs with intact adrenal cortex.

In spite of absence of adrenal insufficiency, acromegalic patients also showed abnormal response. This observation indicates the interference of pituitary other than adrenal cortex.

Diabetes mellitus, diabetes insipidus, hyperthyroidism and obesity showed abnormal responses.

In conclusion, abnormal patterns of insulin eosinopenia indicate the dearrangement of the activity of hypothalamo-pituitary adrenal system, and would render means of interpretating the pathologic physiology of the diseases.

\section{Experimental Carbohydrate Metabolism in vitro and its Critical Analysis \\ By}

\author{
Masaji TAKEDA, Shigeaki BABA and Rokuro NAKA \\ Kobe Medical College, Department of Internal Medicine, Division 2.
}

\section{SUMMARY}

The authors have reported in numbers of occasions ever since 1940 when the studies on carbohydrate metabolism in vitro after Yamamoto's method have been undertaken. At present, the investigation is being made in the efiort to have a contrast with in vitro on the metabolic studies by the use of Warburg's apparatus, and with liver slice and diaphragm method, and subsequent analytical 


\title{
インシユリンこ間腦下垂体副腎系の態度
}

\author{
名古屋大学医学部日比野内科教空 (主任 日比野進教授) \\ 研究員林良宸 \\ 緒言
}

生体が外界汃らの刺㦸に反応し, 内部環境の変化を調整して生命を営んでゆく過程の中には多くの因子が 含まれているが，近来，脳下垂体副腎系の果す役割が Selye

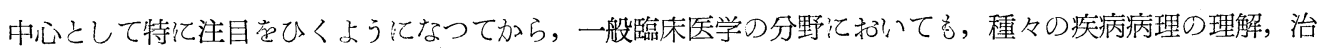
療の実際汇際して, 本系の機能状態を知る事うう, 他の藏器, 器官の機能の分析と共行重要な課題となつて来 た.

脳下垂体副腎系の機能を判定する方法については，副謷皮質のみについてみると，AGTH が精製され31) 49)，臨床的亿ひろく用い得るようになつてからは，それを一定量投与して副腎皮質を特異的，定量的测载

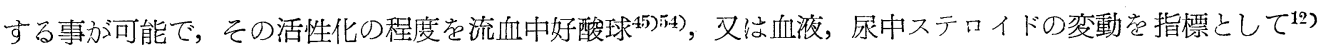

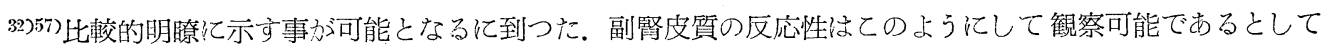
も，副腎皮質の反応性を維持せしぬ，又生体のその時々の要求応じ，その内分泌を調節する上位の下垂

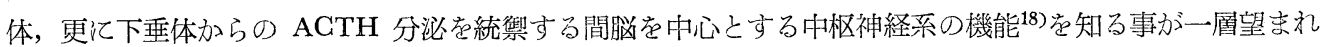
る.

間脳下垂体副腎系を一つの系統として，その機能を臨床的に知るのに良い方法统，現在の所离宗り見られ ない，アドレナリンの注射か間脳下垂体を経由して副腎皮質を活性化せしもるとの考えの下に，その結果の 流血中好酸球減少を ACTH 投与時のそれと比較して下垂体機能検查と与る方法は43354), 必ずしも正しい判 断を与えるものでない事が37 61 既に発表されている。

一方, 脳下垂体ホルモン，殊江生長ホルモンと ACTH，及び副腎皮質ホルモンは，膵臟内分泌たるイン

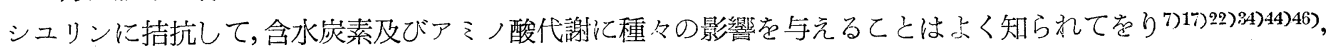
体外より少量のインシュリンを与える事は，乙れらホルモン間の平衡に変化を与えて内部環境の攪乱を起す。 この覺乱の下垂体副腎系に及ぼす影響を追及する事䎲っつて，又，本系の機能変化が存在すると考えられる 症例仁扔いてインシュリン投与による代謝変化の相違を観察する事によつて, 下垂体副婜系の機能をうかが う一手段となる事を考えた。

インシュリン投与が流血中好酸球学減少せしぬ，下垂体副堅系の活性化をひき起す事が既に報告されてを

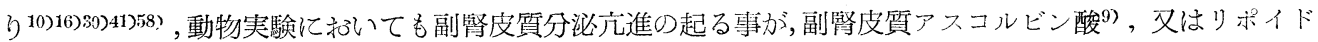

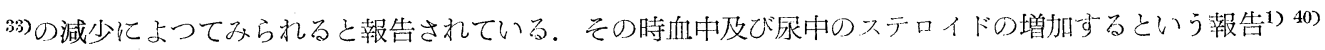

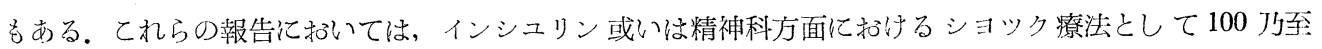
150 単位, 或いは体重 1 聒当り 1 乃至 2 単位を静脈注射する方法で, 極妨て大量であるが, 玨々は25, 体重

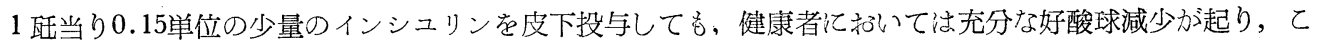
の反応か種々の病的変化を示す条件を検䛉で結果，所謂ホルモンバランスの立場少ら考察して，てれがイ ンシュリンテストとして臨床的に間脳下垂体副腎系の機能検查法として有用な事をみたので，以下てれにつ いて論じてみる。

\section{インシュリンテストの実施方法}

早朝空腹時に・ンンユリンを皮下注射して，それより4 時間に亘つて血糖と流血中好酸球の変動を追及する. 被検者は検查当日は起床以来絶食せしぬ, 午前 8 時乃至 9 時汇試験を開始する。検查施行中は静か䎲横卧 
するか又は椅子に腰かけさせ，欲すれば少量の水を与皇る外，試験中は勿論，一切飲食せしぬない，

インシユリンは逼常インシュリン (Regular insulin) を体重 1 狂てつき0.15単位，上膊外側皮下に注射す

る，注射量の正確を期して，注射器はッベルクリン反応用のそれを用い，針は皮下注射用のなるべく細いも のを用いる。

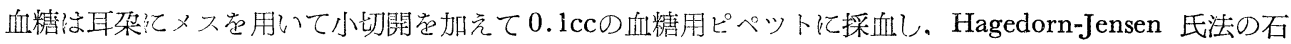
原氏による変法 ${ }^{24)}$ 亿つて測定した。測定はインシニリン注射前, その後30分，1時間，1 時間 30 分， 2 時 間， 3 時間及び 4 時間後䎲行つた。

好酸球の測定住インシニリン注射前及びその後 1 時間每に 4 時間迄行う。血糖と同様亿耳染犸ら白血球計

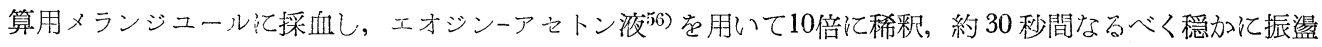
混和してフックスーローゼンタール計算板て满し， 3 分間静置して後, 計算板全区割内 $\left(16 \mathrm{~mm}^{2} \times 0.2 \mathrm{~mm}\right)$

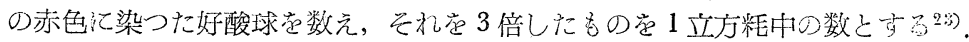

\section{I 健康晢に於げる寒験}

\section{1. 健康者のインシュリンデスト}

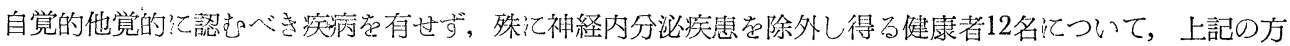
法氾従つて施行した成績は第 1 表江示与ั.

第1表 健康者のインシュリンテスト

\begin{tabular}{|c|c|c|c|c|c|c|c|c|c|c|c|}
\hline \multirow{2}{*}{ 被検者名 } & \multirow{2}{*}{ 情 } & \multirow{2}{*}{ 年悀 } & \multirow{2}{*}{$\begin{array}{l}\text { インシュ } \\
\text { リン 襾 }\end{array}$} & \multicolumn{2}{|c|}{ 血 糖 } & \multicolumn{2}{|c|}{$(\mathrm{mg} / \mathrm{dl})$} & \multicolumn{4}{|c|}{ 好酸球 $\left(/ \mathrm{mm}^{3}\right)$} \\
\hline & & & & 注射前 & 最低值 & 4 垟闆 & 低下率 & 注射前 & 2 時間 & 4 時間 & 減少率 \\
\hline I. H. & $\hat{o}$ & 25 & 7.0 & 84 & 65 & 79 & -28 & 306 & 279 & 66 & -79 \\
\hline O. T. & 우 & 23 & 7.0 & 95 & 87 & 95 & -4 & 261 & 75 & 54 & --79 \\
\hline K. Y. & 令 & 27 & 7.0 & 87 & 70 & 81 & -14 & 105 & 39 & 33 & -68 \\
\hline O.Y. & $\hat{o}$ & 22 & 9.6 & 86 & 67 & 83 & -22 & 405 & 402 & 153 & -62 \\
\hline I..$M$. & $\hat{\delta}$ & 24 & 7.8 & 93 & 57 & 64 & -39 & 627 & 501 & 249 & -60 \\
\hline A. A. & $\hat{o}$ & 24 & 7.0 & 104 & 70 & 95 & -33 & 57 & 45 & 21 & -58 \\
\hline O.N. & $\hat{o}$ & 22 & 8.1 & 92 & 65 & 82 & -11 & 121 & 87 & 52 & -57 \\
\hline $\mathrm{A} \cdot \mathrm{K}$. & $\hat{o}$ & 27 & 8.4 & 84 & 39 & 60 & -29 & 735 & 684 & 330 & -55 \\
\hline M. T. & $\hat{\delta}$ & 31 & 9.0 & 96 & 72 & 81 & -25 & 894 & 580 & 447 & -51 \\
\hline H. X. & 今 & 27 & 7.0 & 118 & 87 & 95 & -4 & 222 & 156 & 111 & -50 \\
\hline O. S. & $\hat{\delta}$ & 30 & 9.0 & 81 & 68 & 69 & -16 & 384 & 393 & 222 & -42 \\
\hline M.Y. & $\hat{\delta}$ & 29 & 9.0 & 121 & 71 & 73 & -41 & 222 & 225 & 135 & -39 \\
\hline
\end{tabular}

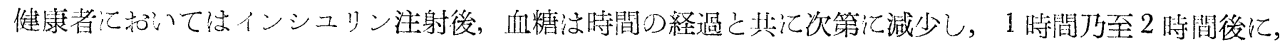

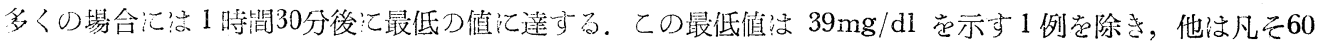

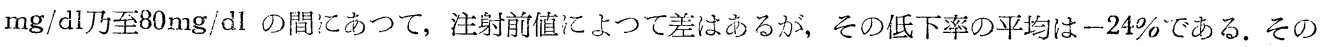
後血糖は上昇し 4 時間後ては注射前值に近く，又はそれ以上に達する。

流血中好酸球は同じく注液後，次第に減少し，多くは 4 時間後に最低に達する. 少数例てれてては 3 時間

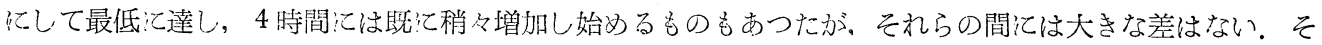
して12例中10例は注射命值刀50\%以上の減少を示し, 残り 2 例汢-42\%, $-39 \%$ の減少率を示した.

この好酸球减少率つ值之空腹時血榶淔, 血糖低下率入大小, 又好酸球刀空腹時絶対数との間には特別の 関連は認められなねつた。

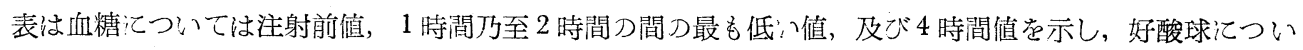


ては注射前値, 2 時間後の值, 及び 4 時間徝を示した.

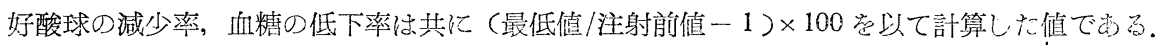

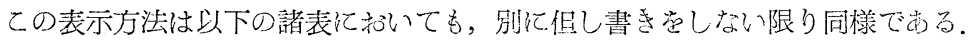

以上の健康者の例和いては，体重 1 呧当り0.15単位のインシュリン皮下注射によ。血結低下は，精神病

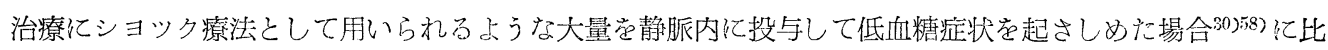
べると，その程度は小さいが，好酸球の方は同様に略々50\%以上の減少を示す。唯，静脈内大量注射の場合 には好酸球減少率がー-90\%にも達する例が苟るに反し，現在のべている少量皮下注射によつてはー79\%に達 するのが最高である。

インシュリンに上可好酸球減少の機棈の説明については，アドレテリン投与纪々る好酸球減少反応と刘比

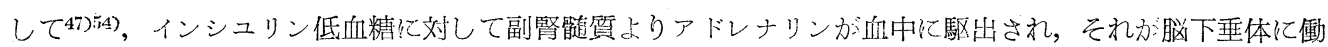

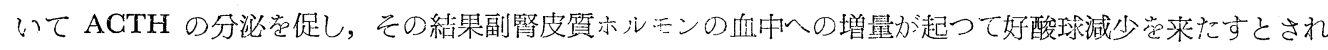

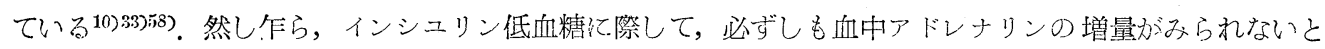

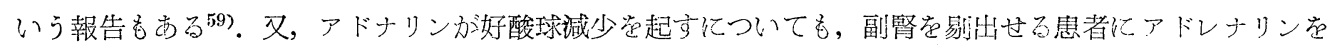

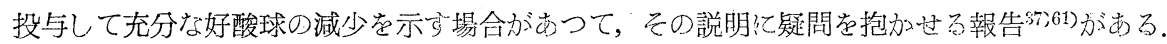

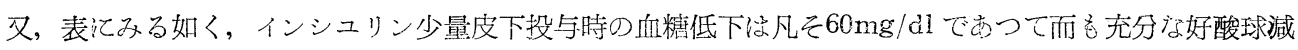
少が起る。静脈内大量投与の報告30)41)では，低血糖症状をあらわす程度の臨界值 ( $35 \mathrm{mg} / \mathrm{dl}$ 以下) 迄血糖低 下が起ると始姑て好酸球減少か $50 \%$ 以上なるとされているが，てれについても稍々異つた成績が得られた。

インシユリン好酸球減少反応には次に述べる如きインシュリンによる血糖低下以外の各種代謝物質の変動 も与つていると考元られるが，又後に述べる実験の如く，全く血糖低下を防ぐとき活好酸球減少反応も阻正:

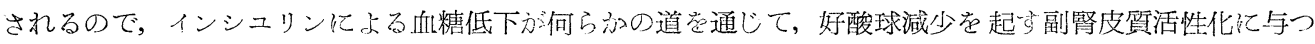
ているものと考えられる.

\section{2. インシュリンによるその他の代謝変化}

インシュリンを体外汃ら投与すると，血糖の低下，好酸球の減少と共に，更晴々の体液成分の変化を示 すととは詳細化亘つて報告があり論議されているが，こつに用いた体重 1 狂当り 0.15 算位皮下注射の場合に き以下㯈べる如变变化がみられた。

好酸球は上述の如く減少を示すに際し，他種白血球は又別の態度をとる。淋巴球は副腎皮質分泌方進によ

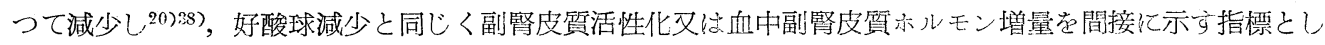

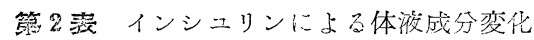

\begin{tabular}{|c|c|c|c|c|c|c|c|c|c|c|c|c|c|}
\hline \multirow{2}{*}{ 成 分 } & \multirow{2}{*}{$\begin{array}{l}\text { 被検者名 } \\
\text { 測定 } \\
\text { 等位 }\end{array}$} & \multicolumn{3}{|c|}{ O.N. 合 22 才 } & \multicolumn{3}{|c|}{ O.Y. 令 22才 } & \multicolumn{3}{|c|}{ I.M. 令 24才 } & \multicolumn{3}{|c|}{ O.S.今 30才 } \\
\hline & & 前 & 2 & 4 & 前 & . 2 & 4 & 前 & 2 & 4 & 前 & 2 & 4 \\
\hline 好 酸 球 & $/ \mathrm{mm}^{3}$ & 121 & 87 & 52 & 405 & 402 & 153 & 627 & 501 & 249 & 384 & 393 & 222 \\
\hline 血 & $\mathrm{mg} / \mathrm{dl}$ & 92 & 65 & 82 & 86 & 67 & 33 & 93 & 57 & 64 & 81 & 68 & 69 \\
\hline 好 球 & $/ \mathrm{mm}^{3}$ & 5015 & 5050 & 14325 & 4360 & 6000 & 9850 & 5560 & 13150 & 9750 & 5830 & 6960 & 17450 \\
\hline 淋 巴球 & $\prime \prime$ & 2056 & 1868 & 2077 & 1700 & 2536 & 1133 & 1720 & 3810 & 1220 & 1600 & 1080 & 3570 \\
\hline ナトリウム & $\mathrm{mEq} / 1$ & 170 & 165 & 168 & 157 & 157 & 155 & 144 & 151 & 143 & 136 & 134 & 141 \\
\hline カリウ & 11 & 5.08 & 4.06 & 4.12 & 5.57 & 5.00 & 5.00 & 4.94 & 3.45 & 3.52 & 5.52 & 5.21 & 4.27 \\
\hline $\begin{array}{l}\text { 遊睢型コレス } \\
\bar{\square}-ル ル 2\end{array}$ & $\mathrm{mg} / \mathrm{dl}$ & 46.5 & 47.5 & 44.8 & 38.3 & 38.3 & 43.7 & 70.5 & 70.5 & 62.5 & 39.4 & 36.2 & 36.2 \\
\hline $\begin{array}{l}\text { エステル型コ } \\
\text { レステロール }\end{array}$ & 11 & 92.5 & 97.5 & 94.2 & 76.5 & 76.5 & 68.3 & 90.5 & 90.5 & 88.5 & 43.6 & 48.8 & 50.8 \\
\hline 無 機 燐 & " & 2.69 & 2.34 & 3.13 & 2.59 & 2.33 & 2.59 & 2.85 & 1.65 & 2.37 & 2.64 & 2.40 & 2.75 \\
\hline
\end{tabular}




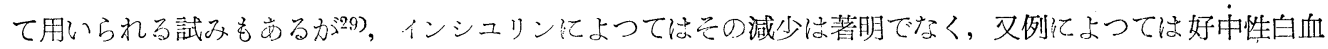
球と同一方向の変動を示すものもあつた。

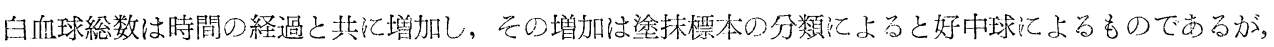

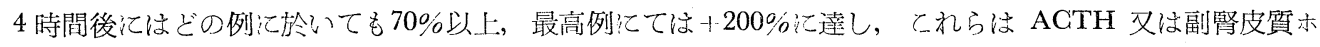
ルモン投与時化比ずへき変動(1)20亿である。

インシユリン投与によつて血中ナトリゥムは殆んど変化しないのに対し，カリウムは減少し，且，その減 少は既にインシュリン注射後 2 時間に括いて著明で，乙の減少はインシュリンによる体細胞内への葡萄糖摂

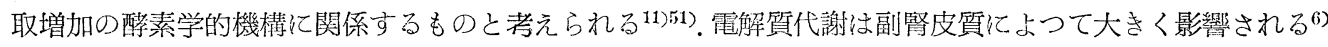
21)36)。然しインシュリン注射時にみられる早期の血中カリウム減少は好酸球減少と同様な副婜皮質活性化亿 よるよりも，インシュリンの体細胞自身への影響と䓅えられる。

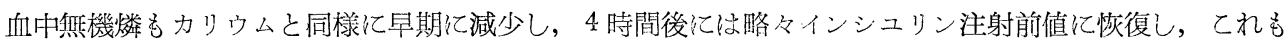
葡萄糖の細胞内移行に与る変化であると考えられる。

血中コレステロールは遊離型，エステル型共に 4 時間内㵔変はない.

\section{3. インシュリン好酸球減少反応を変化せしめるニ, 三の条件について}

健康者のインシュリンによる好酸球減少反応の機構の詳細驻明らかでなく, その説明の一端として, 又, 次項に述べる神経内分泌疾患の患者にみられる反応の変化と比較するため，健康者に神経内分泌系江変動を 与える処置を施した。 その時の好酸球反応怯次の如くである.

\section{(1) 葡萄糖投与}

インシユリンテスト施行に際して, 注射前から終了迄の間, 最初は20分毎に, 後には 30 分毎亿総計 100 瓦 の葡萄糖を経口的に与省ると，血糖は注射前值以下低下する事なく，且，葡萄糖を単独投与したときに比

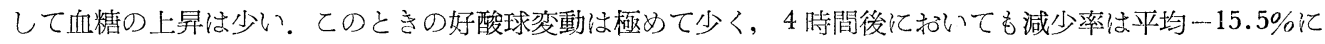
止り，最大の減少率を示方例々和いてもー25\%である.

故にインシュリンによる好酸球減少には先づ血糖低下が与つているととは前にも述べた如く，当然考元ら れる所である。

\section{(2) 交感神経遮断威}

交感神経遮断戍として臨床的に用いられる Tetraethylammonium bromide (TEAB) 200 毝をインシュリ ン注射 10 万至 15 分前化皮下注射したきの血糖低下はインシュリン単独投与時と変りない方，好酸球減少率 は最高一 $25 \%$ であ。，好酸球数変動て与る交感神経系の役割は明瞭沉なていないが，ACTH 投与亿よる 好酸球減少反応は同様な TEAB 処置を行つても，それ它行わないときと等しい好酸球減少率が得られると

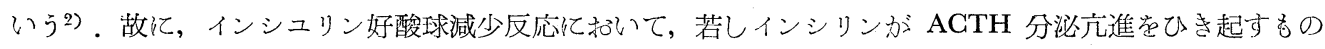

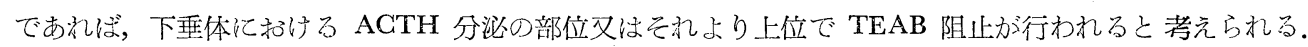
何れにしてもインシユリン好酸球減少反応仙は交感神経系が正常の活動力を有している事が必要であると言 元西.

\section{(3) 睬幹麻醉}

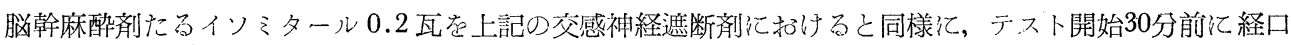

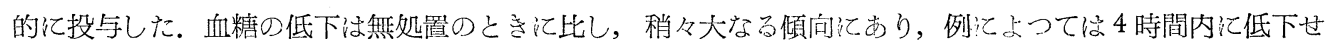

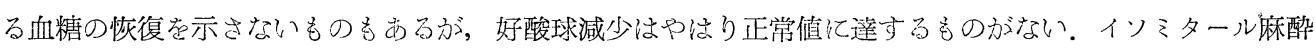
の部位は正確汇決定し得ないが，中枢神経系の下垂体副袩系機能汇関与する事は，その見解は一致しない迄

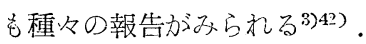

インシユリンによつて50\%以上の好酸球減少を起す健康者䎲対して上記の処置を施した場合は何れも，血

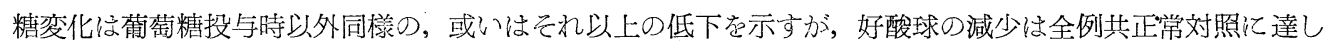

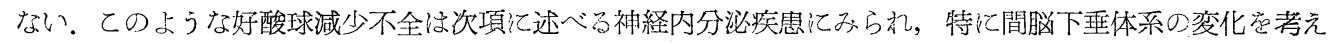
られるもの亿不全型が多い，健康者代於いても中枢神経系，交感神経系がインシュリン好酸球減少反応関 
第3表 健康者に薬剤負荷時の成績

（1）葡 萄 糖 (100 gm)

\begin{tabular}{|c|c|c|c|c|c|c|c|c|c|c|c|}
\hline \multirow{2}{*}{ 被検者名 } & \multirow{2}{*}{ 性 } & \multirow{2}{*}{ 年令 } & \multirow{2}{*}{$\begin{array}{l}\text { インシ } \\
\text { リン 量 }\end{array}$} & \multicolumn{2}{|r|}{ 血. } & \multicolumn{2}{|c|}{ 糖 } & \multicolumn{2}{|c|}{ 好 } & \multicolumn{2}{|c|}{ 球 } \\
\hline & & & & 注射前 & (最高傎) & 4 時:間 & 低下掌 & 注射前 & 2 時間 & 4 時間 & 隇少率 \\
\hline S.Y. & 令 & 30 & 8.7 & 91 & 115 & 80 & - & 372 & 360 & 402 & +8 \\
\hline K. Y. & $\hat{\jmath}$ & 29 & 7.0 & 96 & 148 & 93 & - & 170 & 168 & 134 & -21 \\
\hline S.K. & $\hat{o}$ & 27 & 8.0 & 87 & 122 & 82 & - & 333 & 345 & 253 & -24 \\
\hline T. T. & $\hat{o}$ & 27 & 9.0 & 73 & 113 & 85 & - & 1289 & 1221 & 984 & -25 \\
\hline
\end{tabular}

(2) T E A B (200 mg)

\begin{tabular}{|c|c|c|c|c|c|c|c|c|c|c|c|}
\hline \multirow{2}{*}{ 被検者名 } & \multirow{2}{*}{ 性 } & \multirow{2}{*}{ 年令 } & \multirow{2}{*}{$\begin{array}{l}\text { インシュ } \\
\text { リン 量 }\end{array}$} & \multicolumn{2}{|c|}{ 血 } & \multicolumn{2}{|c|}{ 糖 } & \multicolumn{2}{|c|}{ 好 } & \multicolumn{2}{|c|}{ 球 } \\
\hline & & & & 注射前 & 最低做 & 4 蛙間 & 低下率 & 注射前 & 2 時闃 & 4 時間 & 減少率 \\
\hline O.N. & 今 & 22 & 8.3 & 87 & 77 & 80 & -12 & 447 & 486 & 488 & +9 \\
\hline K. Y. & $\hat{o}$ & 23 & 9.6 & 85 & 61 & - & -28 & 108 & 126 & 105 & -3 \\
\hline I. K. & $\hat{o}$ & 22 & 8.0 & 80 & 60 & 87 & -25 & 217 & 156 & 190 & -12 \\
\hline U.H. & $\hat{o}$ & 22 & 8.5 & 67 & 60 & - & -10 & 237 & 192 & 194 & -18 \\
\hline O. A. & $\hat{o}$ & 21 & 8.5 & 89 & 74 & 80 & -17 & 909 & 963 & 702 & -23 \\
\hline M.Y. & $\hat{o}$ & 23 & 8.5 & 97 & 63 & 71 & -35 & 258 & 249 & 192 & -25 \\
\hline
\end{tabular}

(3) イソミタール (0.2 gm)

\begin{tabular}{|c|c|c|c|c|c|c|c|c|c|c|c|}
\hline \multirow{2}{*}{ 被検者名 } & \multirow{2}{*}{ 性 } & \multirow{2}{*}{ 年令 } & \multirow{2}{*}{$\begin{array}{l}\text { インシュ } \\
\text { リン 量 }\end{array}$} & \multicolumn{2}{|c|}{ 血 } & \multicolumn{2}{|c|}{ 糖 } & \multicolumn{2}{|c|}{ 孖 } & \multicolumn{2}{|c|}{ 球 } \\
\hline & & & & 注射前 & 最低值 & 4 時間 & 倠下率 & 注射前 & 2 時間 & 4 時間 & 減少率 \\
\hline H.Y. & 令 & 30 & 7.0 & 95 & 56 & 67 & -41 & 57 & 48 & 81 & +42 \\
\hline O.N. & $\hat{\delta}$ & 23 & 8.3 & 113 & 62 & - & -45 & 825 & 768 & 828 & 0 \\
\hline K. S. & 今 & 24 & 7.0 & 85 & 42 & - & -50 & 814 & 675 & 678 & -16 \\
\hline O.K. & $\hat{o}$ & 23 & 7.5 & 87 & 56 & 62 & -36 & 201 & 200 & 144 & -28 \\
\hline M.N. & 令 & 25 & 7.3 & 79 & 67 & 81 & -15 & 327 & 354 & 201 & -38 \\
\hline
\end{tabular}

与してをり，それに影響を与える処置力㳔酸球減少反応を不全型て変化せしぬると考えられろ。尚蒇萄糖投 与による実験は，血糖低下が本反応関与している事を示すものである。

\section{II. 各種神経內分泌疾患時におけるインシュリン好酸球減少反応の変化}

上に述ベた少量のインシュリン亿よる好酸球減少反応は健康者に於いて，副㛑皮質以外の神経系に影響を 与える処置によつても変化を示すのであるが，同様偪腎皮質のみならず，間畄下垂体系の異常を有すると 考えられる諸疾患に施行した結果は以下の如くである.

\section{1. 糖尿病}

而糖試験の成績その他によつて真性糖尿病である事を証明された 24 症例のインシュリンテストの成績学第 4 表に示ず如くである.

糖㽷病患者の空腹時血糖值は病症の軽重その他の条件々よつて高低種々であり，0.15単位のインシュリン 皮下注射による血糖低下率の大小は空腹時血糖值と直接関係孔いが，多くの症例て打いて試験中 4 時間々亘 つて低下を続ける，4時間以内に最低值に達し，後血糖上昇を示す例でもその最低值に達する時間は健康者 
より遅く, 多くは 3 時間後である.

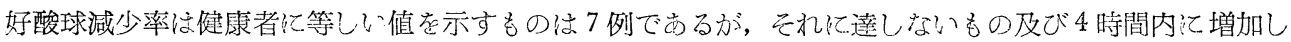
ているものは18例で, 全症例の約 $\%$ 以上占占。，然し，好酸球減少反尤異常のものと正常のものとの間に は，即亏好酸球減少率と血糖值又心血糖低下率との間には関連苍認めなかつた。

糖尿病怯相対的或いは絶対的インシュリン不足がその病像苞形成する主軸であるが，ての点に関連して， 脳下垂体より成長ホルモン及び向副腎皮質ホルモン，副腎皮質より各種ステロイドの分必されるととぶ，主

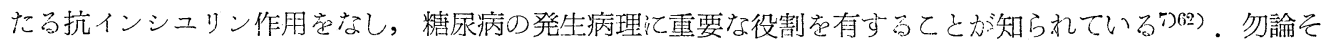

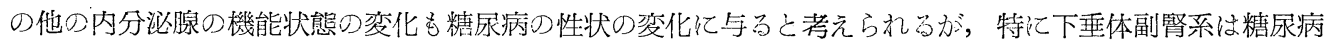

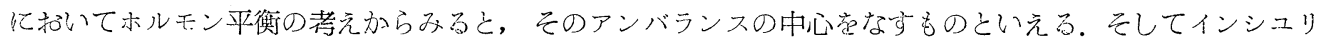

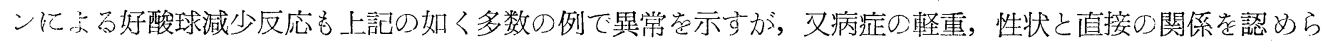

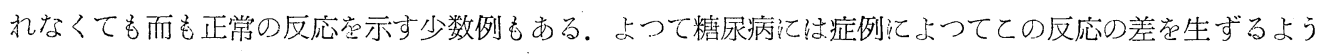
に，下垂体副腎系々中心として血糖並び含水炭素代謝一般関する調節系の変位があると考えら扎る。

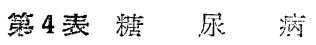

\begin{tabular}{|c|c|c|c|c|c|c|c|c|c|c|c|}
\hline \multirow{2}{*}{ 症 例 } & \multirow{2}{*}{ 年令 } & \multirow{2}{*}{ 性 } & \multirow{2}{*}{$\begin{array}{l}\text { インシニ } \\
\text { リン 量 }\end{array}$} & \multicolumn{2}{|c|}{ 血 } & \multicolumn{2}{|c|}{ 糖 } & \multicolumn{2}{|c|}{ 好 } & \multicolumn{2}{|c|}{ 球 } \\
\hline & & & & 注射前 & 最低值 & 4 時間 & 低下率 & 注射前 & 2 時間 & 4 時間 & 滅少率 \\
\hline K. T. & 68 & $\hat{\delta}$ & 7.5 & 244 & 134 & - & -46 & 195 & 45 & 27 & -85 \\
\hline K. Y. & 15 & $\hat{o}$ & 5.7 & 326 & 157 & - & -52 & 47 & 18 & 15 & -68 \\
\hline K. I . & 52 & $\hat{o}$ & 9.3 & 119 & 87 & 106 & -27 & 401 & 162 & 162 & -60 \\
\hline M. R. & 40 & $\hat{\delta}$ & 7.0 & 124 & 73 & 96 & -30 & 324 & 235 & 147 & -55 \\
\hline W. S. & 51 & $\hat{o}$ & 9.7 & 228 & 118 & - & -48 & 408 & 297 & 186 & -54 \\
\hline Y.H. & 16 & 우 & 7.6 & 238 & 162 & 182 & -32 & 1344 & 768 & 624 & -53 \\
\hline H.R. & 32 & 우 & 7.5 & 208 & 143 & - & -36 & 302 & 225 & 159 & -47 \\
\hline I. Y. & 45 & $\hat{o}$ & 7.0 & 206 & 165 & - & -20 & 225 & 282 & 153 & -32 \\
\hline K. E. & 73 & 오 & 6.0 & 212 & 154 & 191 & -27 & 42 & 30 & 30 & -29 \\
\hline S.K. & 24 & q & 8.0 & 140 & 98 & 123 & -30 & 1518 & 1353 & 1068 & -29 \\
\hline K. S. & 58 & $\hat{\beta}$ & 8.4 & 224 & 100 & 106 & -55 & 933 & 591 & 660 & -29 \\
\hline Y.S. & 43 & $\hat{o}$ & 8.5 & 149 & 110 & - & -26 & 398 & 318 & 297 & -24 \\
\hline H.H. & 14 & 今 & 4.5 & 189 & 87 & 108 & -54 & 222 & 213 & 183 & -18 \\
\hline M.K. & 56 & 오 & 6.0 & 206 & 113 & - & -45 & 519 & 534 & 435 & -16 \\
\hline T.M. & 26 & 우 & 5.2 & 218 & 141 & - & -35 & 177 & 156 & 159 & -10 \\
\hline K.M. & 58 & 우 & 9.5 & 308 & 282 & 288 & -8 & 210 & 252 & 201 & -7 \\
\hline N.K. & 54 & $\hat{o}$ & 9.0 & 117 & 107 & 134 & -9 & 305 & 292 & 285 & -6 \\
\hline Y.T. & 50 & q & 8.0 & 233 & 146 & - & -42 & 795 & 774 & 780 & -2 \\
\hline K. S. & 61 & 우 & 7.0 & 291 & 90 & 93 & -69 & 99 & 57 & 99 & 0 \\
\hline M.T. & 21 & $\hat{o}$ & 8.0 & 106 & 98 & .103 & -8 & 400 & 418 & 460 & +15 \\
\hline N.H. & 54 & $\hat{o}$ & 8.5 & 118 & 90 & 96 & -23 & 768 & 978 & 804 & +16 \\
\hline I. H. & 32 & $\hat{o}$ & 7.2 & 221 & 125 & 170 & -44 & 165 & 99 & 194 & +18 \\
\hline M. T. & 64 & $\hat{\delta}$ & 8.5 & 122 & 73 & 86 & -40 & 315 & 405 & 375 & +19 \\
\hline $\mathrm{K} . \mathrm{K}$. & 23 & 9 & 11.0 & 147 & 89 & - & -40 & 250 & 276 & 327 & +32 \\
\hline K.M. & 48 & 우 & 5.0 & 244 & 193 & - & -21 & 78 & 114 & 117 & +50 \\
\hline
\end{tabular}

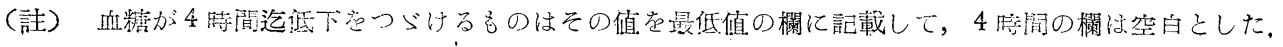


糖疗病思者に ACTH を投与するのは禁忌とされているか，Eik-Nes ${ }^{13)}$ らとるとACTH 静脈内点滴投

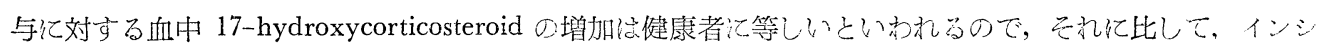
ユリン好酸球減少反応斺く変化を示すとと蛙興味深い事である.

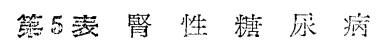

\begin{tabular}{|c|c|c|c|c|c|c|c|c|c|c|c|}
\hline \multirow{2}{*}{ 淀 例 } & \multirow{2}{*}{ 性 } & \multirow{2}{*}{ 年令 } & \multirow{2}{*}{ 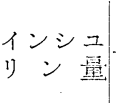 } & \multicolumn{2}{|c|}{ 血 } & \multicolumn{2}{|c|}{ 箬 $(\mathrm{mg} / \mathrm{dl})$} & \multicolumn{2}{|c|}{ 好 } & \multicolumn{2}{|c|}{ 球 } \\
\hline & & & & 注射前 & 最低值 & 4 時溜 & 低下率 & 注射前 & 2 時閐 & 4 時間 & 隇少率 \\
\hline N.K. & $\hat{\delta}$ & 19 & 6.0 & 72 & 54 & 58 & -25 & 58 & 13 & 9 & -85 \\
\hline Y.O. & 오 & 39 & 7.5 & 80 & 52 & 56 & -35 & 84 & 51 & 21 & -75 \\
\hline H. T. & $\hat{o}$ & 52 & 7.8 & 90 & 72 & 90 & -20 & 192 & 156 & 84 & -56 \\
\hline S. I. & $\hat{o}$ & 65 & 7.0 & 84 & 61 & 72 & -22 & 135 & 132 & $81^{\circ}$ & -40 \\
\hline
\end{tabular}

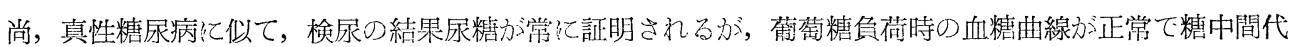

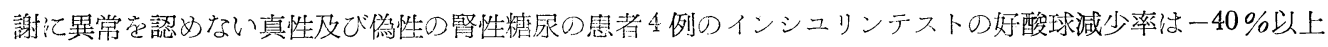

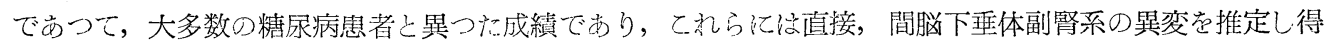
ない.

\section{2. 尿崩症}

第6表尿崩症

\begin{tabular}{|c|c|c|c|c|c|c|c|c|c|c|c|}
\hline \multirow{2}{*}{ 症 例 } & \multirow{2}{*}{ 性 } & \multirow{2}{*}{ 年令 } & \multirow{2}{*}{$\begin{array}{l}\text { インシ } \\
\text { リン 量 }\end{array}$} & \multicolumn{2}{|c|}{ 血 } & \multicolumn{2}{|c|}{ 楛 $(\mathrm{mg} / \mathrm{dl})$} & \multicolumn{2}{|c|}{ 好 } & \multicolumn{2}{|c|}{ 球 } \\
\hline & & & & 注射前 & 最低值 & 4 時䦔 & 低下率 & 注射前 & 2 時䦗 & 4 時間 & 減少率 \\
\hline S.T. & $\hat{\jmath}$ & 48 & 8.0 & 128 & 76 & 132 & -41 & 255 & 235 & 153 & -40 \\
\hline \multirow{2}{*}{ H. H. } & \multirow{2}{*}{ 우 } & \multirow{2}{*}{46} & 7.0 & 140 & 47 & 76 & -66 & 252 & 222 & 141 & -44 \\
\hline & & & 7.5 & 97 & 63 & 84 & -35 & 102 & 123 & 66 & -35 \\
\hline
\end{tabular}

尿崩症の 2 例 3 回の成績では，その好酸球娍少率はー35\%乃至一-40\%であつて，正常に達しないけれども 比較的大である。本症は下垂体後葉亦ルモン分泌不足か病因它なし，下垂体後葉と共に視床下部に於ける神

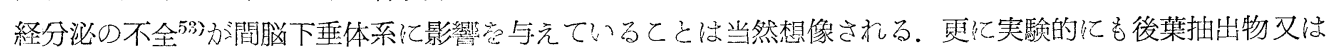
Vasopressin は剔出せ百下垂体放ら ACTH の分泌党增加させる作用犬゙あり48，アシンン氏病の水利尿の不

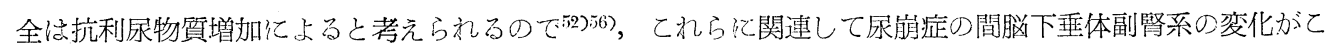
のようなインシュリンテストの変化を示するのであろう.

\section{3. アジソン氏病}

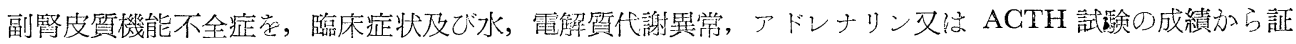
明された 5 症例のインシュリンテストの成績学第 7 表て示す。この内, 症例 S.S.及びN.Y.は経過中副腎 発症を起して入院, 治療により発症は恢復して略々正常の生活学営子得る状態の下に於して施行した成績で

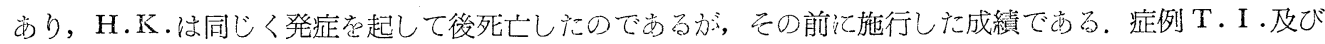
M.Y.は ACTH 20 酕点滴静脈内注射飞上る好酸球減少反応力゙第 1 日には不全型さると反し, 以降同様の

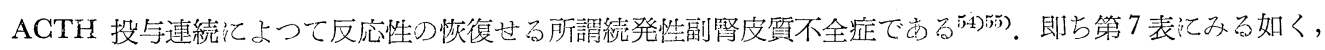

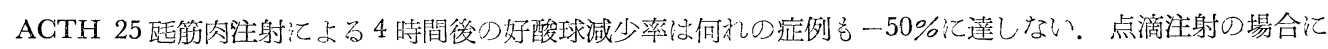

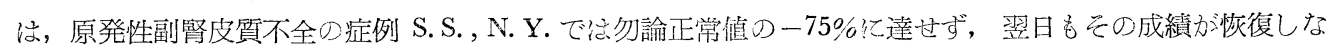
いか，続発性の症例 T. I. , M. Y. では連続投与の第2又は第3日目に正常の反応性定示している.

アドレナリン 0.3 醃注射 4 時間後の好酸球減少率は同じ表に揭げたが，症例 S.S.，T.I.に扔いては夫久 
第 7 表 アジソン氏病

\begin{tabular}{|c|c|c|c|c|c|c|c|c|c|c|c|c|c|c|}
\hline \multirow{2}{*}{ 症洌 } & \multirow{2}{*}{ 性 } & \multirow{2}{*}{ 年令 } & \multirow{2}{*}{$\begin{array}{l}\text { インシュ } \\
\text { リン 㟟 }\end{array}$} & \multicolumn{2}{|r|}{ 血 } & \multicolumn{2}{|l|}{ 糖 } & \multicolumn{2}{|r|}{ 好 } & \multicolumn{2}{|l|}{ 球 } & \multicolumn{2}{|c|}{ ACTHテスト* } & \multirow{2}{*}{$\begin{array}{ll} & \triangle \\
\text { アドレ } \\
\text { ナリン } \\
\text { テスト }\end{array}$} \\
\hline & & & & 注射亩 & 最低值 & 4 時間 & 低下率| & 注射前 & $\mid 2$ 時間 $\mid$ & 4. 時間 & |減少率 & 筋肉注射 & 点滴靜注 & \\
\hline S.S. & $\hat{o}$ & 43 & 8.0 & 70 & 39 & 53 & -44 & 657 & 441 & 453 & -33 & -8 & $\left(\begin{array}{l}-9 \\
-31\end{array}\right.$ & -48 \\
\hline N. Y. & $\hat{o}$ & 32 & 6.8 & 78 & 68 & 78 & -31 & 408 & 351 & 333 & -18 & - & -32 & -27 \\
\hline H.K. & |人 & 33 & 6.8 & - & - & - & - & 450 & 375 & 471 & +4 & +3 & - & - \\
\hline T. I. & $\hat{\delta}$ & 45 & 7.0 & 99 & 55 & 91 & -44 & 69 & 45 & 75 & +10 & +25 & $\left(\begin{array}{l}-32 \\
-89\end{array}\right.$ & -63 \\
\hline \multirow{3}{*}{ M. Y • } & \multirow{3}{*}{$\hat{\delta}$} & \multirow{3}{*}{33} & 8.5 & 80 & 58 & 68 & -27 & 1119 & 1098 & 906 & -29 & +5 & $\left(\begin{array}{r}-62 \\
75\end{array}\right.$ & -7 \\
\hline & & & 8.2 & 76 & 55 & 97 & -28 & 384 & 264 & 228 & -41 & & $\mid \begin{array}{l}-75 \\
-91\end{array}$ & \\
\hline & & & 8.1 & 69 & 31 & 69 & -55 & 282 & 322 & 207 & -26 & & -74 & \\
\hline
\end{tabular}

* ACTH 䇢肉注射は ACTH 25 I.U.在筋注後, 4 㭙間の㶩酸球減少率を示与。

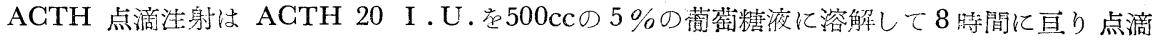
注射，注射開始後12時閒の好酸球隇少率を示し，括孤で結んだものは后一点滴を德日繰返した 時の值起示す.

$\triangle$ アドレナリン $0.3 \mathrm{mg}$ 皮下注射後 4 時閒の好酸球減少率

-48\%，-63\%であつて，アドレナリン好酸球減少反応力゙必ずしも副筒皮質，脳下垂体值接関係のない場 命があるという3761)例を示している。

インシュリンテストの成績は副腎皮質不全症のどの例ても正常の反応がタられなかつた。症例M.Y.に抏 いては ACTH 連日投与亿より反応性の恢復がみられても，その前後に扔いて，インシュリン亿対する反応 は不全であつた。

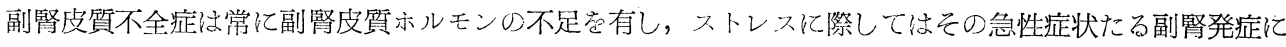
陥るが，ACTH，アドレナリンに対する好酸球減少反応か不全であると同じく，ーインシュリンによつても全 例正常の減少な示さない.インシュリンに上る好酸球減少注前にも述ベた如く間脳下垂体系の機能状態に大 きく左右され吕事が考えられるのであるが，短時間内に好酸球の減少のみられるのは，他の刺㦸方法に上る 場合でも intactな副腎皮質の存在の下に或いは副瞥皮質分泌増進に条件づけられて起るものであり ${ }^{14) ， イ ン ~}$ シュリンによつても同様と間脳下垂体副緊系の末端の器官たる副腎皮質の欠損によつては本反応は全く不全 な形となるのである。

第8表末端肥大症

\begin{tabular}{|c|c|c|c|c|c|c|c|c|c|c|c|c|c|}
\hline \multirow{2}{*}{ 症例 } & \multirow{2}{*}{ 性 } & \multirow{2}{*}{ 年令 } & \multirow{2}{*}{$\begin{array}{l}\text { インシユ } \\
\text { リン 量 }\end{array}$} & \multicolumn{2}{|r|}{ 血 } & \multicolumn{2}{|c|}{ 糖 } & \multicolumn{4}{|c|}{ 好 醡 球 } & \multicolumn{2}{|c|}{ AGTHテスト* } \\
\hline & & & & 泩射前 & 最低值 & $\begin{array}{l}4 \text { 塒 } \\
\text { 間值 }\end{array}$ & 低下率 & 洼射前 & 2 時間 & 4 特間 & 減少率 & 静肉注射 & 点滴靜泩 \\
\hline \multirow{2}{*}{$\mathrm{K} . \mathrm{K}$. } & \multirow{2}{*}{$\hat{\delta}$} & \multirow{2}{*}{49} & 7.0 & 114 & 73 & 91 & -36 & 375 & 303 & 303 & -15 & \multirow{2}{*}{+9} & \multirow{2}{*}{-97} \\
\hline & & & 8.0 & 162 & 83 & - & -49 & 343 & 343 & 375 & +12 & & \\
\hline $\mathrm{K} . \mathrm{Ka}$ & 㑒 & 35 & 8.0 & 85 & 61 & 69 & -28 & 243 & 282 & 87 & -64 & - & - \\
\hline \multirow{2}{*}{ S.M. } & \multirow{2}{*}{ 令 } & \multirow{2}{*}{28} & 13.5 & 92 & 71 & 80 & -23 & 504 & 519 & 630 & +25 & \multirow{2}{*}{-3} & \multirow{2}{*}{-82} \\
\hline & & & 14.7 & 94 & 78 & 78 & -17 & 609 & 651 & 588 & -1 & & \\
\hline T.Y. & 우 & 41 & $\begin{array}{l}11.0 \\
10.5\end{array}$ & $\begin{array}{r}96 \\
156\end{array}$ & $\begin{array}{l}63 \\
95\end{array}$ & -75 & $\begin{array}{l}-34 \\
-39\end{array}$ & $\begin{array}{l}159 \\
148\end{array}$ & $\begin{array}{l}234 \\
174\end{array}$ & $\begin{array}{l}208 \\
120\end{array}$ & $\begin{array}{l}+31 \\
-19\end{array}$ & -8 & -76 \\
\hline T.S. & 东 & 29 & 10.5 & 89 & 69 & 76 & -27 & 303 & 297 & 360 & +22 & -17 & -26 \\
\hline
\end{tabular}

*註は前䘚に同じ 


\section{4. 末端肥大症}

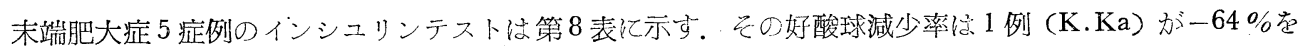

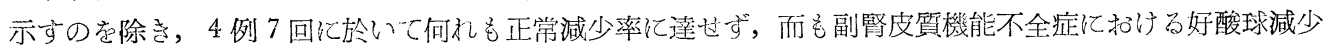
不全が 4 時間の值が増加ずるものでも10\%ぶ最高であるのに反し未端肥大症て抽いては好酸球増加の例が多 く，且，その堌加の率が大である。乙の上うな好酸球の增加は糖尿病の一部の症例にもみられ，糖尿病と末

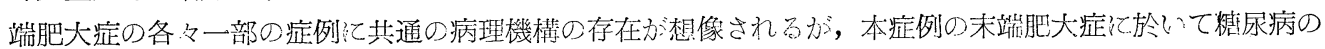
証明されたのは1例 (K.K.) の子であつた。

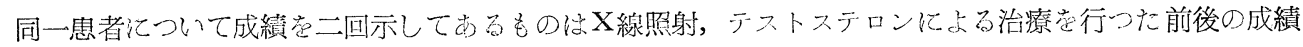

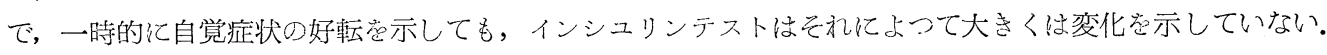

末端肥大症は成長ホルモン過剩によるものであり，成長ホルモンは下垂体の糖尿病惹起作用の主たる役割 を演(゙7)44)，又下垂体内で成長ホルモン産生が他種ホルモン産生と拈抗する事は副腎ステロイド，性ホルモ

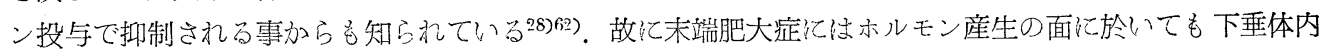
の変位 (Shift) が䓅えら机，下垂体副腎系仁起り得る変化も又大でであるととが考えられる。

尚，ACTH 投与対する好酸球減少率は 25筋肉内注射後 4 時間では，各例共に一50\%の正常值に達し

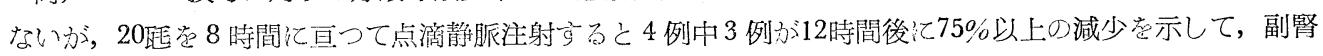
皮質の反応性飞異常ふ認められない。乙のような筋肉注射と静脈注射沉る ACTH の效果の差がみられる のは，ACTH 在不活性化する物質か混在して4)，末端肥大症にはそれを促進する局所の条件加存在するも のと考えられる2().

\section{5. 甲状腺機能㐫僬症}

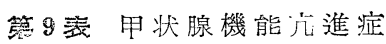

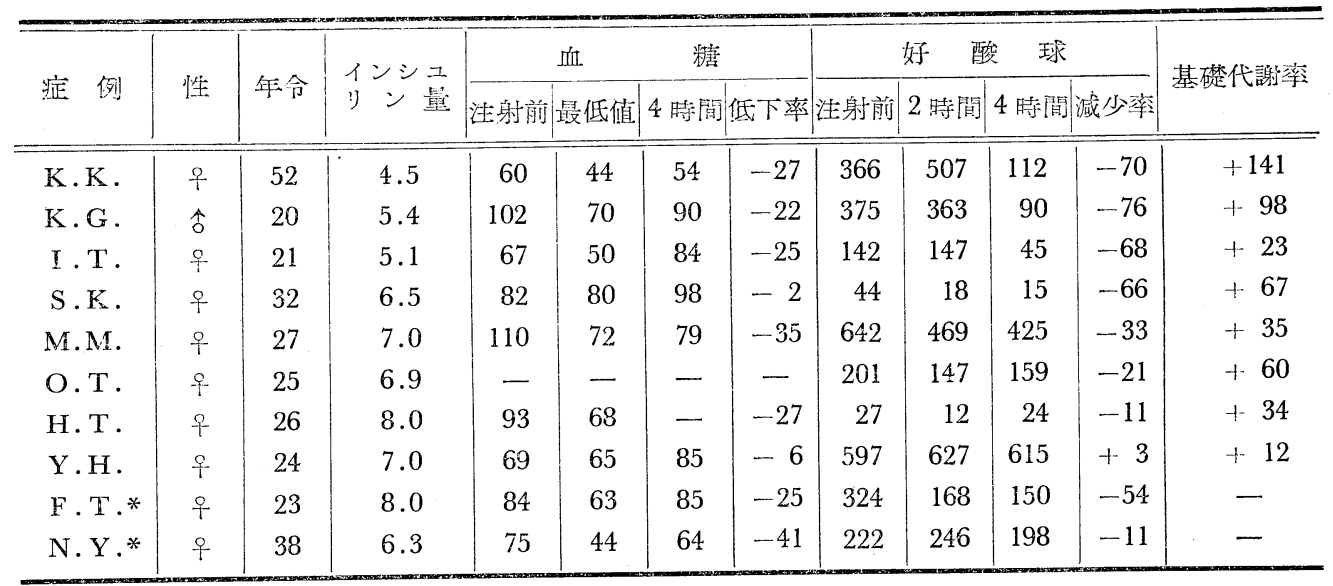

* 甲状腺切除後

甲状腺機能九進症を有する10例のインシュリンデトの成績索，インシュリンデト施行時に最も近い時 に測定した基礎代謝率の值と共飞第 9 表に示す。そこの内，治療として甲状腺切除觉行つた後のもの 2 例九含

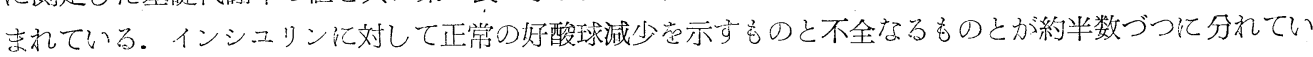
るのがみられる。乙れらの症例では有意の差ではないが, 基礎代謝九進の大なるもの程好陖球減少率が大で

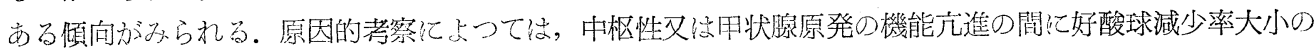
差镬妨られなかつた。

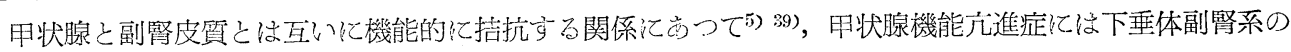
変化の存在し得る場合のある事は充分推察し得る. 又, 本症には甲状腺自身の原発的失調によるものと原因 
が中枢神経系或いは脳下垂体に存在するものがあり，䄞に後者の場合は他種内分泌系統への影響は大である と考光ら礼号涼。

木症のインシュリンテストの成績は各症例によつて種々な值を示したが，不全例に执てはてれらの原因

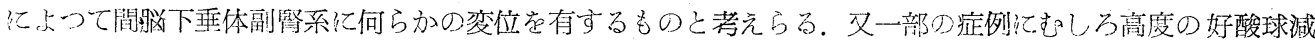

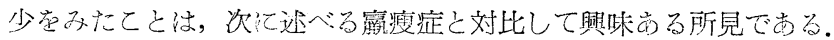

\section{6. 覇瘦症}

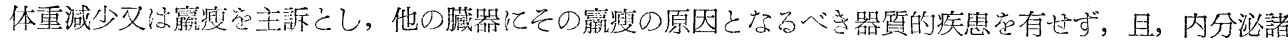

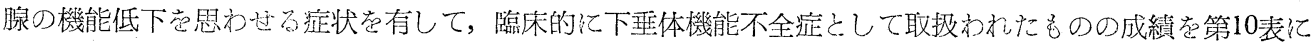
示す。てれらの患者驻その他の機能检查の成績及び臨床症状が，所謂 Simonds 氐病又は Sheehan 氏病の症

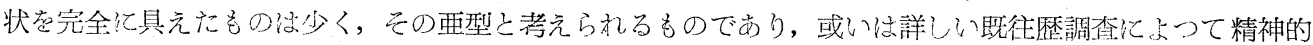

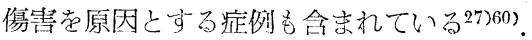

管10表浧症

\begin{tabular}{|c|c|c|c|c|c|c|c|c|c|c|c|c|}
\hline \multirow{2}{*}{ 症 例 } & \multirow{2}{*}{ 性 } & \multirow{2}{*}{ 知令 } & \multirow{2}{*}{$\begin{array}{c}\text { 体重 } \\
\mathrm{kg}\end{array}$} & \multirow{2}{*}{$\begin{array}{l}\text { インシュ } \\
\text { リン 量 }\end{array}$} & \multicolumn{4}{|c|}{ 血 } & \multicolumn{4}{|c|}{ 好 酸 } \\
\hline & & & & & 注射前 & 最低值 & 4 時間 & 低下学 & 注射前 & 2 時間 & 4 時䦓 & 㺂少莩 \\
\hline A. T. & 우 & 20 & 40 & 6.0 & 71 & 48 & 54 & -32 & 24 & 0 & 0 & -100 \\
\hline W. S. & q & 33 & 41 & 6.0 & 91 & 51 & 93 & -41 & 120 & 39 & 12 & -90 \\
\hline K.H. & 옴 & 29 & 39 & 6.0 & 109 & 76 & 107 & -30 & 303 & 129 & 39 & -87 \\
\hline Y.H. & q & 26 & 39 & 6.0 & 73 & 41 & 61 & -42 & 60 & 48 & 18 & -70 \\
\hline M. T. & p & $2 !$ & 37 & 5.7 & 84 & 70 & 67 & -12 & 171 & 108 & 54 & -68 \\
\hline S.H. & 㑒 & 19 & 36 & 5.5 & 75 & 42 & 67 & -44 & 204 & 171 & 78 & -62 \\
\hline T.K. & 우 & 33 & 35 & 5.5 & 96 & 69 & 74 & -28 & 189 & 66 & 75 & -60 \\
\hline N.M. & $\hat{o}$ & 21 & 38 & 5.8 & 86 & 71 & - & -18 & 104 & 60 & 51 & -52 \\
\hline $\mathrm{K} . \mathrm{T}$. & $\hat{b}$ & 17 & 43 & 6.5 & 83 & 69 & 73 & --27 & 63 & 69 & 30 & -52 \\
\hline H.H. & 우 & 32 & 27 & 4.0 & 77 & 55 & 84 & -28 & 87 & 54 & 45 & -48 \\
\hline I. A. & 우 & 21 & 30 & 4.5 & 71 & 44 & 57 & -38 & 57 & 33 & 48 & -47 \\
\hline K.S. & 우 & 18 & 33 & 5.0 & 98 & 52 & 61 & --15 & 405 & 414 & 313 & -18 \\
\hline $\mathrm{O} . \mathrm{H}$. & 우 & 21 & 30 & 4.5 & 71 & 44 & 57 & -38 & 57 & 33 & 48 & -16 \\
\hline I. H. & $\hat{\delta}$ & 16 & 27 & 4.0 & 78 & 66 & 99 & -55 & 414 & 342 & 414 & 0 \\
\hline
\end{tabular}

そしててのような患者仙は脳下垂体機能不全の結果，インシュリンテストの成績も又異常で岁万うと想像

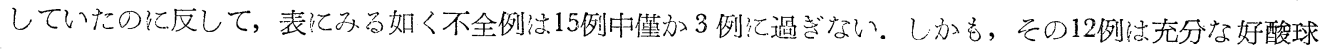
減少を示し，症例によつては正常にみられるよりも大なる減少率を示するのも尚る。东，てれらの患者のイ ンシュリン注射前好酸球絶対值の小なる例が多いという所見と共に, 果してての減少率か泟常と考えてよい

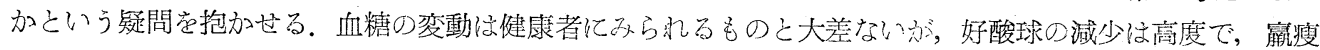
症沉於いて，間脳下垂体副腎系の変位があるとすれば，その機構结稍々興味ある問題である。

第11表・肥㭌症

\begin{tabular}{|c|c|c|c|c|c|c|c|c|c|c|c|c|}
\hline \multirow{2}{*}{ 淀 例 } & \multirow{2}{*}{ 性 } & \multirow{2}{*}{ 年令 } & \multirow{2}{*}{$\begin{array}{c}\text { 体且 } \\
\mathrm{kg}\end{array}$} & \multirow{2}{*}{$\begin{array}{l}\text { インシュ } \\
\text { リン 鱀: }\end{array}$} & \multicolumn{4}{|c|}{ 血 } & \multicolumn{4}{|c|}{ 好 䣲 球 } \\
\hline & & & & & 注射前 & 最低值 & 4 特等同 & 低下季 & 洼射前 & 2 時間 & 4 時間 & 減少洆 \\
\hline I.K. & $\hat{o}$ & 11 & 50 & 7.5 & 67 & 60 & 80 & -11 & 585 & 599 & 423 & -23 \\
\hline A. T. & 우 & 39 & 60 & 9.0 & 128 & 90 & 142 & -10 & 192 & 216 & 147 & -23 \\
\hline M. T. & $\hat{o}$ & 36 & 67 & 10.0 & 93 & 80 & - & -14 & 201 & 192 & 156 & -22 \\
\hline
\end{tabular}




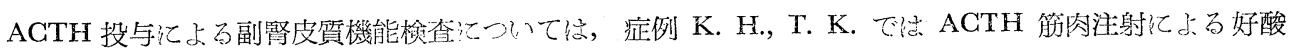

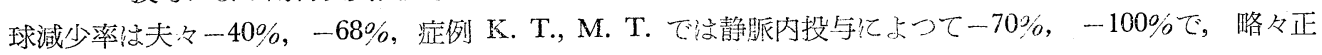
常の值を示した。

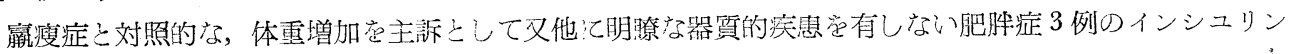
テストは 3 例とも不全であつた。

\section{7. 関節ロイマチスム, 其の他}

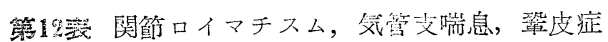

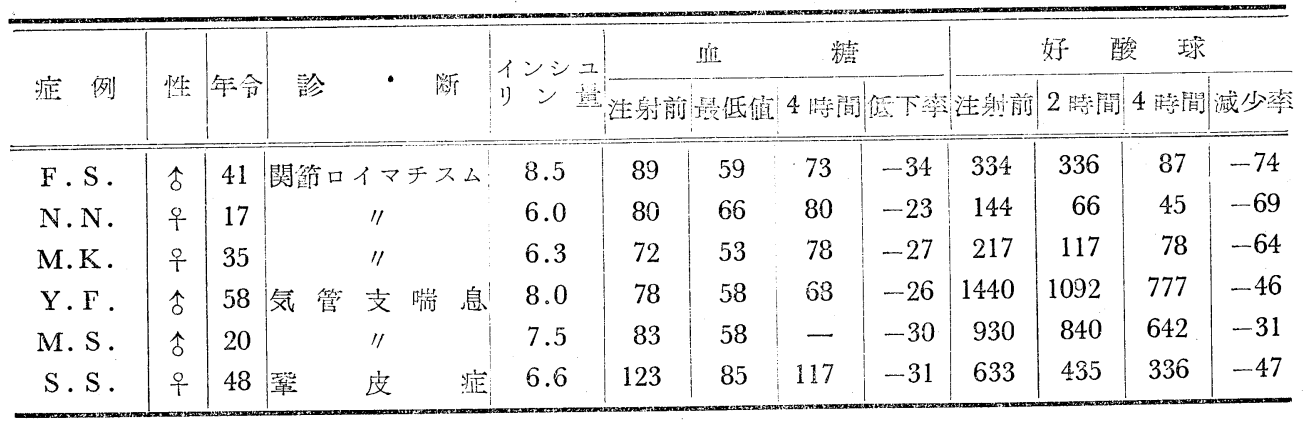

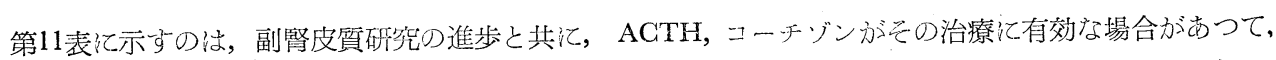

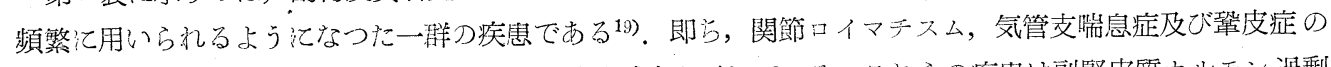
インシニリンテストは，何れも正常に近い好酸球減少を示してい。こ纪らの疾患は副腎皮質ホルモン過剩

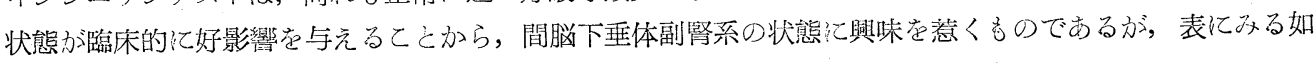
くインシユリン反応て著変荧認めなかつた。

\section{III. 要約}

脳下垂体副腎系は膵臟内分泌たるインシュリンに拮抗的な㗢きを以て，生体ホルモン平衝の一翼究構成し ているが，逆体外からインシュリンを投与すると，その平衝行衝擊を与え，その結果，体液諸成分の種々

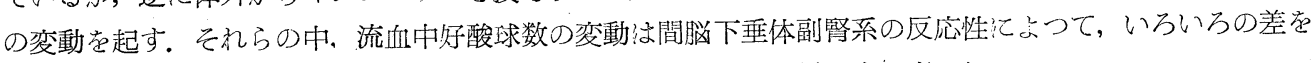
示すので, 之を指徱として本系の機能をうかがう方法として用い得る事を考えた。

即ち, 早朝空腹時沉, 体重 1 酕当り 0.15 単位Dイシシュリンを皮下注射すると, 健康者に扔いて 4 時間後に 50\%の好酸球減少営ひき扣てすので，乙の方法定インシュリンテストとして各種条件下に試多た結果は次の 如くであつた.

健康者て执いて, 葡萄糖投与亿占血糖低下防止の処置力好酸球減少をも阻止する。父交感神経遮断剤, 脳幹麻酔剂の投与亿よつても，正常反応引シ阻止される。

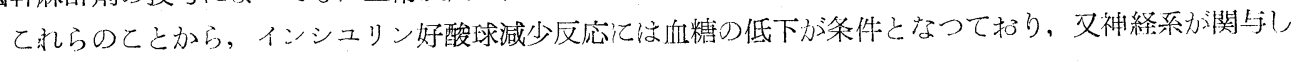
ている事方洘光られ。。

副筲皮筫不全症ては全例共，正常反応子゙办られない，即ちインシユリン好酸球減少反応には健全な副腎皮 質の存在が必要である。

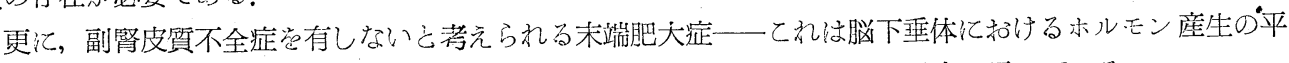
衡か変化していると考えられる一D症例でも好酸球変動侣健康者淤ける場合と異つている。

其刀他, 糖军病, 尿崩症, 甲状腺疾思, 肥胖症等刀間脳下垂体系の変化がその病因の一部をなしている諸 疾病ても，多くの症例て和いてインシュリン好酸球減少反応の変化がみられた。

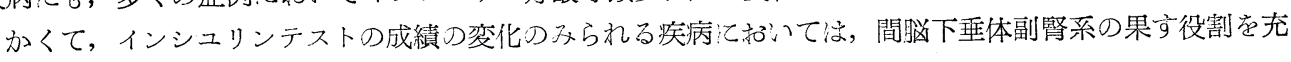

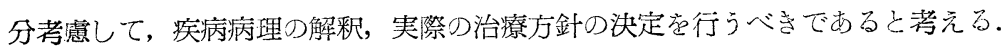


終始, 御懇切な御指導を睗わつた日比野教授並びに環境医学研究所石原助教授に愿く感謝いたします。

文献

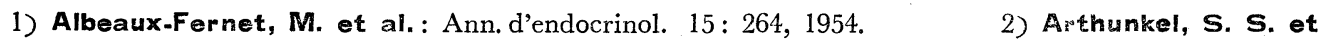
al.: J. Clin. Endocrinol. \& Metab. 13 : 1122, $1953 . \quad$ 3) Briggs, F. N. \& Munson, P. L.: J. Clin. Endocrinol. \& Metab. $14: 811,1954$.

4) Cohen, H. et al. : J. Clin. Endocrinol. \& Metab. $14: 1013,1954 . \quad$ 5) Conner, C. S.: Endocrinology 55: 45, $1954 . \quad$ 6) Danowski,

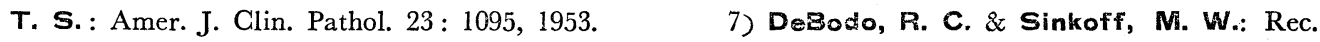
Progr. Hormone Res. $8: 511,1953 . \quad$ 8) Dougherty, T. F. \& White, A. : J. Lab. \& Glin. Med. $32:$ 584, 1947. $\quad$ 9) Dury, A. : Amer. J. Physiol. 163: 96, 1950.

10) Dury, A. : Endocrinology $47: 387,1950 . \quad$ 11) Dury, A.: Endocrinology $53: 564,1954$.

12) Eik-Ness, $K$. et al. : J. Clin. Invest. $33: 1502,1954 . \quad 13)$ Eik-Ness, K, et al.: J. Glin. Endocrinol. \& Metab. $15: 13,1955$ 14) Essellier, A. F. et al.: Blood $9: 531,1954, \quad$ 15) Forsham, P. H. et al.: J. Clin. Endocrinol. 8: 15, $1948 . \quad$ 16) Goldowski, Z. Z.: Brit. Med. J. 1: $46,1950$. 17) Griffin, A. C. et al.: J. Biol. Chem. 209, $1954 . \quad$ 18) Harris, G. W.: Physiol. Rev. 28 : 139, 1948.1 19) Hench, P. S. et al.: J. Amer. Med. Assoc. 144: 1327, $1950 . \quad$ 20) Hills, A. G. et al.: Blood 3:755, $1948 . \quad 21$ ) Hills, A. G. er al. : J. Clin. Invest. 32: 1236, 1953. 22) Houssy, B. A. et al. : J. Exp. Med. $75: 547,1942 . \quad 23)$ 飯田, 外: 日本內科学会雑誌, 41:

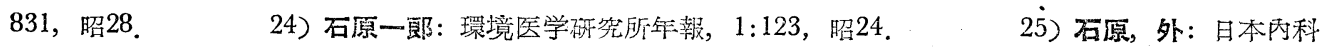
学会雑誌, 41:740, 昭28. 26 ) Ishihara, I. et al. : J. Glin. Endocrinol. \& Metab. in press. 27) Israel, S. L. : J. Amer. Med. Assoc. 148: 189, $1952 . \quad$ 28) Kinsell, L. W. er al.: J. Clin. Endocrinol. $8:$ 1013, $1948 . \quad$ 29) Kumagai, L. F. \& Dougherty, T. F.: Endocrinology $55: 90$, 1954. 30) Laragh, J. H. \& Almy, T. P.: Proc. Soc. Exp. Biol. Med. 69: 499, 1948.

Li, C. H. et al.: J. Biol. Chem. $149: 413,1943 . \quad 32$ ) Lidd!e, G. W. et al. J. Clin. Endocrinol. \& Metab. $14: 837,1954 . \quad 33$ ) Long, C. N. H. \& Gersberg, H.: J. Glin. Endocrinol. $8: 587,1948$.

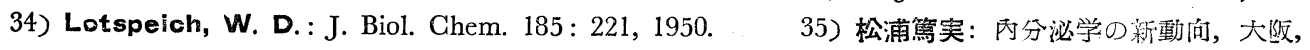
昭25. 36) Mendelsohn, M. L. \& Pearson, O. H.: J. Clin. Endocrinol. \& Metab. 15: 409, 1955. 37) Meyer, R. J.: J. Clin. Endocrinol. \& Metab. 13: 123, $1953 . \quad 38$ ) Nelson, D. H. et al.: J. Glin. Invest. $31: 843,1952$. 39) O'Neal, L. N. \& Heinbecker, P.: Endocrinology 53: 60, $1953 . \quad 40)$ Paschkis, K. E. et al.: Endocrinology $47: 338,1950 . \quad$ 41) Porlmutter, M. \& Mufson, M.: J. Clin. Endocrinol. 11: 277, 1951. $\quad$ 42) Porter, R. W.: Rec. Progr. Hormone Res. 10: 1, $1954 . \quad$ 43) Recant, L. et al.: J. Clin. Endocrinol. $10: 187,1950.4$ 44) Reid, E.: J. Endocrinol. $9: 210,1953 . \quad 45)$ Renold, A. E. et al. : J. Clin. Endocrinol. 12: 763,

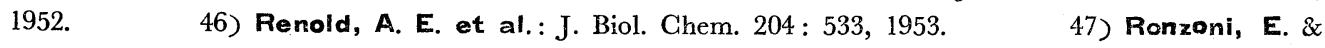
Reichlein, S.: Amer. J. Physiol. 160:490, $1950 . \quad 48)$ Saffran, M. et al.: J. Clin. Endocrinol. \& Mteab. 15: 840, $1955 . \quad$ 49) Sayers, G. et al.: J. Biol. Chem. 149: 425, $1943 . \quad 50)$ Selye, H.: The Physiology and pathology of exposure to stress. Montreal, $1950 . \quad 51)$ Sheppard, C. W.: Science $144: 2952,1951 . \quad 52)$ Slessor, A.: J. Glin. Endocrinol. $11: 700,1951 . \quad 53)$ Smith, H.: The Kidney, NewYork, $1951 . \quad 54)$ Thorn, G. W. et al.: J. Amer. Med. Assoc. 137 : 1005, $1948 . \quad 55)$ Thorn, G. W. et al.: Rec. Progr. Hormone Res. $4: 229,1948 . \quad 56)$

Thorn, G. W.: The diagnosis and treatment of adrenal insufficiency. Illinois, $1949 . \quad 57)$ Thorn, G. W. : Rec. Progr. Hormone Rec. 8 : 171, 1953. $\quad$ 53) Tsai, S. Y.: Pro. Soc. Exp. Med. Biol. 69 : 782, $1950 . \quad$ 59) Weil-Mahlerbe, H. \& Bone, A. D. : J. Endocricol. $11: 285,1954$. 60) Whitaker S. R. F. et al.: Brit. Med. J. 1:265, 1954, $\quad$ 61) Wolfson, W. Q. : J. Clin. Endocrinol. \& Metab. 13 : 123, $1953 . \quad$ 62) Youg, F.G.: Rec. Progr. Hormone Rec. 8: $471,1953$. 